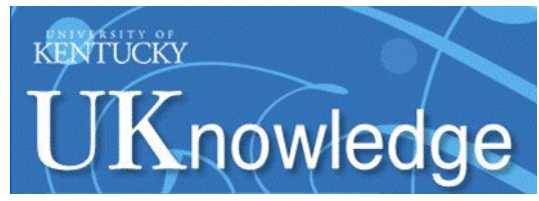

University of Kentucky UKnowledge

\title{
4-2001
}

\section{Aluminium Toxicokinetics: An Updated MiniReview}

Robert A. Yokel

University of Kentucky, ryokel@email.uky.edu

Patrick J. McNamara

University of Kentucky, pmcnamar@email.uky.edu

Right click to open a feedback form in a new tab to let us know how this document benefits you. Follow this and additional works at: https://uknowledge.uky.edu/ps_facpub

Part of the Pharmacy and Pharmaceutical Sciences Commons 


\title{
Aluminium Toxicokinetics: An Updated MiniReview
}

\author{
Digital Object Identifier (DOI)
}

https://doi.org/10.1111/j.1600-0773.2001.880401.x

\section{Notes/Citation Information}

Published in Pharmacology \& Toxicology, v. 88, issue 4.

(C) Pharmacology \& Toxicology 2001

This is the peer reviewed version of the following article: Yokel, R. A., \& McNamara, P. J. (2008). Aluminium toxicokinetics: An updated minireview. Pharmacology \& Toxicology, 88(4), 159-167, which has been published in final form at https://doi.org/10.1111/j.1600-0773.2001.880401.x. This article may be used for non-commercial purposes in accordance with Wiley Terms and Conditions for Use of SelfArchived Versions. This article may not be enhanced, enriched or otherwise transformed into a derivative work, without express permission from Wiley or by statutory rights under applicable legislation. Copyright notices must not be removed, obscured or modified. The article must be linked to Wiley's version of record on Wiley Online Library and any embedding, framing or otherwise making available the article or pages thereof by third parties from platforms, services and websites other than Wiley Online Library must be prohibited. 


\title{
Aluminum toxicokinetics: An updated mini-review
}

\author{
Robert A. Yokel, Ph.D. and Patrick J. McNamara, Ph.D. \\ College of Pharmacy and Graduate Center for Toxicology \\ University of Kentucky Medical Center \\ Lexington, KY 40536-0082
}

Running title: Aluminum toxicokinetics

Address all correspondence to:

Robert A. Yokel, Ph.D.

Professor

College of Pharmacy

501b Pharmacy Building

Rose Street

University of Kentucky Medical Center

Lexington, KY 40536-0082, USA

Phone: 859-257-4855

Fax: $859-257-7585$

email: ryokel1@pop.uky.edu 
This MiniReview updates and expands the MiniReview of aluminum toxicokinetics by Wilhelm et al. published by this journal in 1990 . The use of ${ }^{26} \mathrm{Al}$, analyzed by accelerator mass spectrometry, now enables determination of Al toxicokinetics under physiological conditions. There is concern about aluminum in drinking water. The common sources of aluminum for the human are reviewed. Oral Al bioavailability from water appears to be about $0.3 \%$. Food is the primary common source. Al bioavailability from food has not been adequately determined. Industrial and medicinal exposure, and perhaps antiperspirant use, can significantly increase absorbed aluminum. Inhalation bioavailability of airborne soluble Al appears to be about $1.5 \%$ in the industrial environment. Al may distribute to the brain from the nasal cavity, but the significance of this exposure route is unknown. Systemic Al bioavailability after single underarm antiperspirant application may be up to $0.012 \%$. All intramuscularly injected Al, e.g. from vaccines, may eventually be absorbed. Al distributes unequally to all tissues. Distribution and renal excretion appear to be enhanced by citrate. Brain uptake of Al may be mediated by Al transferrin and Al citrate complexes. There appears to be carrier-mediated efflux of Al-citrate from the brain. Elimination half-lives of years have been reported in the human, probably reflecting release from bone. Al elimination is primarily renal with $\leq 2 \%$ excreted in bile. The contribution of food to absorbed $\mathrm{Al}$ needs to be determined to advance our understanding of the major components of $\mathrm{Al}$ toxicokinetics. 


\section{Overview}

This mini-review will update and expand on topics covered by Wilhelm et al. (1990), incorporating recent reviews and original research reports. It will focus on the pharmacokinetics of Al that influence its potential to produce toxicity from the common sources to which humans are exposed. This will enable identification of the primary circumstances that might contribute to Al accumulation and toxicity. Research advances in the past decade include estimates of Al bioavailability under conditions that model drinking water Al consumption and from inhalation and transdermal exposure. This MiniReview will also address recent studies on the extent of Al distribution to and retention by the brain and bone and the extent of biliary Al excretion. A significant advance in $\mathrm{Al}$ research is the use of ${ }^{26} \mathrm{Al}$ and its analysis by accelerator mass spectrometry (AMS). Their use enables the study of $\mathrm{Al}$ toxicokinetics at physiologically-relevant doses/concentrations.

\section{The toxicity, sources, speciation and analysis of Al}

Al has been shown in animals and humans to have the potential to be a toxicant to the central nervous, skeletal and hematopoeitic systems (contributors to Yokel and Golub, 1996 \& 1997; Health Canada, 1998; ATSDR, 1999; California EPA, 2000; Cannata Andía, 2000). There are suggestions of Al-induced nephrotoxicity and pulmonary fibrosis (Jeffery et al. in Yokel \& Golub, 1996 \& 1997; ATSDR, 1999). Al is a neurotoxicant. Large elevations in systemic Al from Al-contaminated dialysates and intravenous fluids, oral consumption of large amounts of Al-containing antacids/phosphate binders by people with significantly impaired or no renal function, and irrigation of the urinary bladder with massive amounts of alum to stop hemorrhaging can produce an encephalopathy. Encephalopathy from Al exposures that cause large increases in systemic Al has greatly decreased, but not disappeared, over the past two decades. It has been suggested that low level long-term exposure to Al may be a contributing factor in Alzheimer's disease $(\mathrm{AD})$ and related disorders. The results of some epidemiological studies of the association between drinking water $\mathrm{Al}$ and $\mathrm{AD}$ are consistent with this hypothesis while some others are not (Health Canada, 1998; California EPA, 1999; Yokel, 2000). Similarly, only some of the studies that determined $\mathrm{Al}$ in bulk brain, neurofibrillary tangles and senile plaques of victims of AD and related disorders are consistent with this hypothesis (Yokel, 2000). A recent study investigating adverse effects on the central nervous system of Al welders found an Al-exposure-related increase in blood and urine Al 
concentrations, deficits in neuropsychological test performance and mild diffuse EEG abnormalities (Riihimäki et al., 2000). The potential for Al-induced neurotoxicity in those occupationally exposed to $\mathrm{Al}$ fumes may be greater than previously suspected. There is developing concern about adverse effects of Al on neurobehavioral development (Golub and Domingo in Yokel and Golub, 1996 \& 1997). This issue has not been extensively investigated. Although $\mathrm{Al}$ contamination of dialysates has decreased over the past two decades, $\mathrm{Al}$ is still a major causative agent in the low bone turnover diseases, osteomalacia and adynamic bone (Cannata Andía, 2000). An initial indicator of elevated systemic Al is often an anemia due to decreased hemoglobin synthesis.

The primary Al sources for the human are in Table 1. Its presence in drinking water derives from natural sources and water treatment methods. Water treatment generally increases the percentage of dissolved, small molecular weight, chemically reactive, and possibly more readily absorbed, Al species (LaZerte et al. in Yokel \& Golub, 1997; Health Canada, 1998). Although water is the most extensively studied Al source, it provides only about $1 \%$ of normal daily human intake (Table 1). The primary normal source of $\mathrm{Al}$ for the human is food (Table 1). The Al content of foods is highly variable (Pennington, 1987; Greger \& Surtherland, 1997). The major contributors to the human diet are food products containing Al in food additives, such as grain products, processed cheese, and salt (Pennington, 1987; Nieboer et al. 1995). Occupational Al exposure occurs primarily in Al processing and welding, and can significantly increase Al exposure and produce neurotoxicity (Sjögren et al. in Yokel \& Golub, 1997; Riihimäki et al, 2000). Al exposure can result from the use of $\mathrm{Al}$ chlorohydrate in antiperspirants. Common iatrogenic sources are vaccines; Al hydroxide, used as both an antacid and a phosphate binder; and Al contamination in hemodialysis fluids and iv solutions, including total parenteral nutrition solutions (Greger \& Sutherland, 1997). As a result of the concern about $\mathrm{Al}$ in the latter, particularly to the very young human, the United States Food and Drug Administration now requires that Al concentrations be under $25 \mu \mathrm{g} / \mathrm{L}$ in large volume parenteral drug products used in total parenteral nutrition (US FDA, 2000).

$\mathrm{Al}$, as $\mathrm{Al}^{3+}$, is found in various chemical species in the above sources and in vivo. These species have different physical, chemical and biological properties (Harris et al. in Yokel \& Golub, 1996 \& 1997). The solubility of $\mathrm{Al}^{3+}$ is lowest at $\mathrm{pH}$ 6.2. Acidic and alkaline solutions, as well as some complexing ligands, increase its solubility. The toxicokinetics of Al species can vary greatly. The information available on Al species from thermodynamic modeling suggests there are two primary Al species in plasma and one in brain extracellular fluid (Table 2). The effective equilibrium constant, a ratio of the concentration of all reaction products in solution to the concentrations of the reactants, indicates the affinity of the ligand for Al 
at $\mathrm{pH}$ 7.4. Considerations of $\mathrm{Al}$ distribution into tissues and out of the brain should focus on these predominant species. Even though ligand exchange reactions with $\mathrm{Al}$ are slow, there is very little kinetic data on pre-equilibrium $\mathrm{Al}$ species.

The naturally occurring isotope of $\mathrm{Al}$ is ${ }^{27} \mathrm{Al}$. It was the only isotope used in $\mathrm{Al}$ research until the past decade. ${ }^{27} \mathrm{Al}$ is ubiquitous. Al is most commonly quantitated by electrothermal atomic absorption spectroscopy (ETAAS), which has a detection limit of $\leq 1 \mu \mathrm{g} / \mathrm{l}$. Al contamination can derive from airborne particulates, reagents used to digest and dilute samples, glass labware and insufficiently cleaned labware of any composition that comes into contact with the sample. Contamination is often encountered and has rendered many studies useless, particularly those measuring $\mathrm{Al}$ in blood and brain at very low concentrations. Contamination can produce false elevations in the apparent Al concentration. ETAAS determines total Al. Al speciation requires a separation method prior to $\mathrm{Al}$ analysis when ETAAS or another destructive analytical technique is used to quantitate Al. The percentage of Al absorbed from most exposure routes is very small. Therefore, researchers had to administer amounts of Al that were $>10$-fold the human daily Al intake in food or $>1000$-fold the daily $\mathrm{Al}$ intake in water to be able to investigate the influence of oral $\mathrm{Al}$ intake on $\mathrm{Al}$ in blood, urine, or tissue. In the past decade accelerator mass spectrometry (AMS) has been applied to the quantitation of ${ }^{26} \mathrm{Al}$ (Flarend \& Elmore, 1998), enabling the study of extremely small Al concentrations. A disadvantage is the high cost of AMS analysis.

\section{Al bioavailability}

$\mathrm{Al}$ is absorbed from all routes of exposure that have been investigated. Its bioavailability is very dependent on the route of exposure. This section will review the major routes of exposure and current estimates of bioavailability.

\section{A. Oral bioavailablity}

Oral exposure has been the most extensively studied route of $\mathrm{Al}$ absorption. It provides the greatest $\mathrm{Al}$ exposure for most people. However, in selected populations, it is not the route that provides the greatest risk of systemic $\mathrm{Al}$ accumulation and toxicity.

\section{Methods to determine oral Al bioavailability}

Bioavailability (fractional absorption) is the amount absorbed compared to the amount administered. For Al, systemic bioavailability, the 
fraction that ultimately reaches systemic circulation from which it has access to the target organs of its toxicity, is most relevant. Three methods to estimate Al bioavailability were discussed by Wilhelm et al. (1990). Method \#1 is balance studies. In Method \#2 absorption is based on urinary excretion/dose. Method \#3 compares areas under the plasma concentration-time curve after oral and iv administration. A limitation of Method \#2 to estimate bioavailability is that it does not account for the Al that is retained, excreted by non-renal routes, or excreted by the kidneys after study completion. A number of studies have used urinary Al excretion plus tissue $\mathrm{Al}$ to partially overcome this limitation. Another method used in recent human studies is estimation of absorption from a single blood sample $\times$ the estimated volume of distribution, to calculate the $\%$ of the dose in plasma. This method underestimates bioavailability because it does not account for $\mathrm{Al}$ that has been excreted prior to sample collection, $\mathrm{Al}$ that has distributed out of the vascular compartment, or the $\mathrm{Al}$ that is absorbed after sample collection. The method does not assure peak serum $\mathrm{Al}$ was sampled unless independently determined. It has been concluded that bioavailability estimates based on incomplete blood data have considerable error (Priest et al. 1996). These studies are not included in this MiniReview.

\section{Bioavailability of the Al in drinking water}

Several studies have estimated oral Al bioavailability using conditions relevant to Al consumption in drinking water. They used Al doses that reasonably compare with daily oral intake from water by humans $(0.1 \mathrm{mg}, \sim 1.5 \mu \mathrm{g} / \mathrm{kg}$, Table 1$)$ and introduced the $\mathrm{Al}$ as a free ion, as might be found in drinking water, or used water from municipal water suppliers. Results of these studies are shown in Table 3. There are no good data to indicate if Al bioavailability from water is dose/concentration dependent. These results suggest that oral $\mathrm{Al}$ bioavailability from water is in the range of 0.05 to $0.4 \%$; and most likely $\sim 0.3 \%$.

Recognition of Al bioavailability and neurotoxicity lead the U.S. Environmental Protection Agency to put Al on its Contaminant Candidate List (US EPA, 1998). The Agency felt additional research on Al was needed as part of the consideration for development of drinking water regulations and guidance. The Canadian Government established an operational guidance value of $<100 \mu \mathrm{g} \mathrm{Al} / 1$ in treated water from conventional treatment plants 
(Health Canada, 1998). California proposed a public health goal for Al in drinking water (California EPA, 2000).

\section{Bioavailability of the Al in beverages and foods}

Although food comprises the primary source of $\mathrm{Al}$ for the typical human ( $>90 \%$, Table 1$)$, there are very little data on oral Al bioavailability from foods, or beverages other than water. It has generally been assumed that oral Al bioavailability from food is less than from water due to Al incorporation in high molecular weight, relatively insoluble, complexes (Health Canada, 1998). For example, a much lower percentage of the Al in tea was in chemically labile species, 15\%, than in drinking water, 61-75\% (Stauber et al. 1999). Reiber et al. (1995) suggested that a substantial portion of Al, regardless of the chemical species consumed, will be solubilized to monomeric Al in the stomach and subsequently converted to poorly soluble Al species in the near neutral $\mathrm{pH}$ of the upper intestine. As the stomach is not an important site of $\mathrm{Al}$ absorption, this implies that oral Al bioavailability should be $\mathrm{Al}$ species independent. Citrate and other ligands influence Al absorption, suggesting this hypothesis is an oversimplification. Stauber et al. (1999) estimated Al bioavailability from drinking water and food in humans and found it to be comparable from these two sources, $\sim 0.3 \%$. Al bioavailability from food was based on 24-hour urinary $\mathrm{Al}$ excretion during the second day of consumption of a controlled diet. This diet provided $\sim 3000 \mu \mathrm{g}$ Al/day, which is below typical dietary intake (Table 1). Absorption of Al from food consumed prior to the study, which likely provided $>3000 \mu \mathrm{g}$ Al/day, may have contributed to the urinary Al excretion during the study. This would produce an over-estimation of Al bioavailability from the controlled diet. Others have attempted to estimate oral Al bioavailability from food by comparing 1) average daily urinary Al excretion and 2) average daily Al intake from food. Daily urinary Al excretion has been estimated to be 4-12 $\mu \mathrm{g}$ (Nieboer et al. 1995). Average daily Al intake by adults in the US is estimated to be 5000$10,000 \mu \mathrm{g}$ (see Table 1). This suggests an Al bioavailability from food of $\sim 0.1 \%$.

If Al bioavailability from the diet is indeed $0.1 \%$, then food, not water, provides the major source of Al absorbed daily (Table 1 ). Al bioavailability from water would have to exceed that from food by $\sim 50$ to 100 -fold for water to be the primary source of absorbed Al. The limited published data suggest that oral Al bioavailability from food is in the same range as from water, suggesting food provides the majority of Al that is absorbed by the 
typical human.

\section{The influence of food and dietary components on oral Al absorption}

It has been assumed that the presence of food in the stomach inhibits $\mathrm{Al}$ absorption, due to $\mathrm{Al}$ association with organic ligands in food. Only a few studies directly addressed this hypothesis. Walton et al. (1994) conducted an ambitious study to assess the influence of beverages and foods on oral Al absorption. Their results show increased peak serum Al concentration and urinary Al excretion after co-administration with orange juice, and to a much smaller extent, coffee and wine. Meat and a carbohydrate/cereal product decreased Al absorption. However, neither the blood nor urine samples obtained hourly for 4 hours after dosing enable determination of oral Al bioavailability. Druecke et al. (1997) reported $0.94 \%$ oral ${ }^{26} \mathrm{Al}$ bioavailability in 24 -hour fasted rats versus $0.06 \%$ in free-feeding rats. However, rodents and rabbits recycle their feces to increase essential nutrient absorption and usually have stomach contents 24-36 hours after food removal, suggesting the fasted rats may have had stomach contents. In contrast, Yokel et al. (2001) did not find a difference in oral ${ }^{26} \mathrm{Al}$ bioavailability in rats exposed to a procedure that resulted in no stomach contents versus rats that did have chow in their stomachs (Table 3).

The addition of calcium and magnesium carbonates, modeling hard water, did not affect oral Al bioavailability from water (Yokel et al. 2001). There is not much evidence that food in the stomach or water quality significantly affect oral Al bioavailability. There are also no good reported data from which one can estimate the relative bioavailability of Al from beverages and food, other than Al plus citrate in solution compared to water, discussed below.

Health Canada (1998) reviewed the factors affecting Al absorption. They cited evidence that low pH, increased solubility of the Al species, the presence of citrate and other small organic acids, and uremia increase Al absorption whereas phosphorus and perhaps silicon reduce Al absorption. The pH can greatly influence Al speciation, and presumably Al bioavailability. The ability of citrate to increase oral Al bioavailability has received much attention. Three proposed mechanisms; citrate enhanced Al solubility in the gut, transport of Al citrate into mucosal cells, and citrate opening of epithelial 
tight junctions, were reviewed by Greger \& Sutherland (1997). The different times of peak serum Al and citrate after Al citrate consumption suggest Al was not released into blood as $\mathrm{Al}$ citrate (Taylor et al. 1998). Other carboxylic acids similarly enhance $\mathrm{Al}$ absorption from $\mathrm{Al}$ hydroxide, although less effectively. It has been suggested that this is due to enhanced $\mathrm{Al}$ solubility. Phosphate and $\mathrm{Al}$ inhibit each other's absorption, due to formation of insoluble $\mathrm{Al}$ phosphates. Conversely, $\mathrm{Al}$ absorption increases as solution $\mathrm{pH}$ decreases from the nadir of $\mathrm{Al}$ solubility. $\mathrm{Al}$ fluoride produced higher plasma $\mathrm{Al}$ concentrations than $\mathrm{Al}$ chloride (Allain et al. 1996), raising concern about the presence of both $\mathrm{Al}$ and $\mathrm{F}$ in drinking water. Silicon, as monomeric silicic acid, forms soluble hydroxyaluminosilicate whereas oligomeric silica forms a more stable complex (Jugdaohsingh et al. 2000). Silicon reduced gastrointestinal absorption of ${ }^{26} \mathrm{Al}$ (consumed in orange juice, a source of citrate) by $85 \%$ in fasted humans (Edwardson et al. 1993). Silicon may abrogate citrate-enhanced Al solubility. However, Drueke et al. (1997) did not find an effect of co-administered $\mathrm{Si}$ on absorption of ${ }^{26} \mathrm{Al}$ given with citrate to rats after eating. Jugdaohsingh et al. (2000) found inhibition of ${ }^{26} \mathrm{Al}$ absorption by the poorly absorbable oligomeric, but not the absorbable monomeric silica, perhaps explaining the discrepancies in the above results.

\section{The influence of biological factors on oral Al absorption}

Uremia appears to increase Al absorption by increasing gut permeability of the paracellular pathway (Greger \& Sutherland, 1997). There are suggestions in the literature that oral Al bioavailability is greater in the weanling than growing rat and increases in the aged and Alzheimer diseased human. In contrast, oral Al bioavailability was not found to be significantly different between adult humans aged 36-59 versus 59-76 years old (Stauber $e t$ al. 1999). These studies do not provide convincing evidence to resolve the important question whether oral Al bioavailability is age related.

\section{Oral bioavailability from drugs}

The published data on oral bioavailability of Al species relevant to drugs includes Al hydroxide; the antacid sucralfate; Al lactate, which is used in dental products for sensitive teeth; and $\mathrm{Al}$ in the presence of citrate. As shown in Table 1, antacids/phosphate binders have the potential to produce the greatest increase of absorbed $\mathrm{Al}$ of all $\mathrm{Al}$ sources. This presents a problem when these products, which usually contain $\mathrm{Al}$ hydroxide, are consumed in large amounts 
by those who have impaired or no renal function. This practice, along with contaminated dialysate, which is largely avoided today, has produced most of the cases of Al-induced toxicity. The use of Al hydroxide by renal patients continues in some parts of the world. Citrate and other small carboxylic acids can increase $\mathrm{Al}$ absorption, as noted above.

Wilhelm et al. (1990) cited much of the work conducted with ${ }^{27} \mathrm{Al}$, which of necessity, used large doses of Al. Priest et al. (1996) estimated oral Al bioavailability from 6-day urinary ${ }^{26} \mathrm{Al}$ output in 2 subjects. Both received intragastric dosing of ${ }^{26} \mathrm{Al}$ incorporated into $\mathrm{Al}$ hydroxide, ${ }^{26} \mathrm{Al}$ hydroxide in the presence of citrate, and ${ }^{26} \mathrm{Al}$ citrate. Estimates of the percentage of ${ }^{26} \mathrm{Al}$ absorbed from ${ }^{26} \mathrm{Al}$ hydroxide in the absence and presence of citrate averaged $0.01 \%$ and $0.14 \%$, respectively. Al bioavailability from ${ }^{26} \mathrm{Al}$ citrate was $0.52 \%$. These limited results mirror many reports showing very low Al bioavailability from $\mathrm{Al}$ hydroxide (and sucralfate) and augmentation by citrate. Oral Al bioavailability from Al hydroxide appears to be less than from food or water. However, as noted in Table 1, the daily intake of Al from $\mathrm{Al}$ hydroxide-based antacids can greatly exceed that from the diet and water.

\section{The site and mechanisms of absorption of ingested Al}

The proximal intestine appears to be the primary site of Al absorption (Greger \& Sutherland, 1997). Absorption of Al was suggested to be a twostep process, uptake by mucosal cells followed by much slower release into blood (Wilhelm et al. 1990). Evidence that mucous in the gastrointestinal tract can bind Al, to retard and perhaps inhibit its absorption (Powell et al. 1999), suggests a third-step. Greger \& Sutherland (1997) identified the putative mechanisms of absorption; passive (diffusion) and active (carrier- and vesicular-mediated transport) processes across intestinal cells as well as paracellular diffusion between these cells. They reviewed the evidence for absorption of Al by paracellular diffusion and active transport. The active processes that have been suggested to mediate intestinal $\mathrm{Al}$ absorption include mechanisms of $\mathrm{Ca}$ uptake such as $\mathrm{Ca}$ channels, $\mathrm{Na}$ transport processes, and a role for transferrin (Greger \& Sutherland, 1997; van der Voet \& de Wolff, 1998). The calcium and iron status of the animal inversely influence Al absorption. Transferrin addition to the vascular perfusion medium of the isolated rat intestine increased vascular $\mathrm{Al}$, suggesting a role for transferrin mediating $\mathrm{Al}$ release from mucosal cells into blood. 


\section{B. Absorption of inhaled Al}

Inhalation exposure results from cosmetic, occupational and environmental Al sources. The only data amenable to Al bioavailability estimates are from occupational exposure. Occupational exposure to Al fumes, dusts and flakes can elevate serum, bone and urine Al. It is not known if the Al is absorbed from the lung or from the gastrointestinal tract after mucociliary clearance because experimental studies have not isolated the pulmonary from other absorption routes. The rapid increase of $\mathrm{Al}$ in the serum and urine after Al fume exposure suggested pulmonary absorption (Sjögren et al. 1985). Fractional Al absorption by industrial employees was $\sim 1.5-2 \%$, based on the relationship between urinary Al excretion and the airborne soluble Al to which they were exposed (Gitelman et al. 1995; Pierre et al. 1995; Sjögren et al. in Yokel \& Golub, 1997). Pulmonary Al absorption appears to be more efficient than gastrointestinal absorption.

\section{Intranasal absorption}

It has been suggested that $\mathrm{Al}$ may directly enter the brain from the nose through olfactory neurons, which run from the roof of the nasal cavity to the olfactory bulb. Tjälve \& Henriksson (1999) reviewed the anatomy of this process and the published studies with metals. Inorganic cadmium, mercury and nickel were found in the olfactory bulb after their introduction into the rat nasal cavity, but not in other brain regions. This suggests they lack the ability to cross synapses in the olfactory bulb, to distribute to other neurons. In contrast, manganese was found in numerous brain regions (demonstrating transsynaptic distribution).

Implantation of Gelfoam ${ }^{\circledR}$ saturated with $\mathrm{Al}$ lactate or $\mathrm{Al}$ chloride solution into the nasal recess of rabbits for one month resulted in neuropathological changes and elevated Al in the brain (Perl \& Good, 1987). Limited results in rats exposed to Al chlorohydrate by inhalation showed Al in brain stem nuclei, also suggesting olfactory nerve uptake and trans-synaptic Al distribution (Divine et al. 1999). However, there are no data that could be used to estimate Al bioavailability following intranasal exposure to indicate whether this represents a significant route of exposure.

\section{Transdermal absorption}


$\mathrm{Al}$ salts, such as Al chlorohydrate, are extensively used in antiperspirants. They suppress eccrine sweating by forming a hydroxide precipitate in the sweat duct or by denaturing keratin in the cornified layer that surrounds the opening of the sweat duct. Neither mechanism would suggest significant $\mathrm{Al}$ absorption through the sweat duct. A study of $\mathrm{Al}$ absorption following single underarm applications of ${ }^{26} \mathrm{Al}$ chlorohydrate to two subjects suggested up to $0.012 \%$ of the ${ }^{26} \mathrm{Al}$ might eventually be absorbed, presumably through the skin (Flarend et al, 2001). It is not known if comparable $\mathrm{Al}$ absorption would continue to occur from daily application, which would determine if this source of Al might significantly contribute to daily Al absorption (Table 1). The authors suggest that interaction of $\mathrm{Al}$ with the sweat duct would reduce subsequent $\mathrm{Al}$ absorption.

\section{E. Systemic appearance of Al after parenteral administration}

Intravenous $\mathrm{Al}$ administration creates the potential risk of $\mathrm{Al}$ accumulation and toxicity due to $100 \%$ bioavailability and the avid $\mathrm{Al}$ binding by transferrin that prevents rapid clearance. Similarly, exposure to Al-contaminated dialysate can result in diffusion of Al into plasma and its retention by transferrin. Manifestations of the resulting Al-induced toxicity are described in Health Canada (1998) and California EPA (2000). To ascertain Al bioavailability following intramuscular injection, and the potential for vaccines to contribute to $\mathrm{Al}$ exposure, Flarend et al. (1997) administered ${ }^{26} \mathrm{Al}$ hydroxide or ${ }^{26} \mathrm{Al}$ phosphate adjuvants (which did not contain allergens) to two rabbits. Comparison of blood ${ }^{26} \mathrm{Al}$ to one rabbit that received iv ${ }^{26} \mathrm{Al}$ citrate suggested that all of the injected Al may eventually be absorbed, even from these insoluble Al species. Therefore, iv Al exposure from dialysis, total parenteral nutrition or other solutions as well as intramuscular exposure from the 20 vaccinations given in the first 6 years of life or a typical treatment regimen of allergen extract immunotherapy could constitute significant sources of absorbed Al (Table 1). The daily Al exposure to dialysis solution is based on $110 \mathrm{l} /$ dialysis thrice weekly and to total parenteral nutrition solution is based on $0.1 \mathrm{l} / \mathrm{kg} /$ day and $2 \mathrm{l} /$ day in neonatal/pediatric and adult patients, respectively.

\section{Distribution}

Al distributes unequally to all tissues throughout normal and Al- intoxicated humans (Alfrey et al. 1980; Di Paolo et al. 1997) and Al-treated 
experimental animals (Greger \& Sutherland, 1997). The volume of distribution of Al in animals, reviewed by Wilhelm et al. (1990), suggests an initial distribution consistent with blood volume. Within blood, $\mathrm{Al}$ is $\sim$ equally distributed between plasma and cells. The higher concentration in lung of normal humans may reflect entrapment of airborne Al particles whereas the higher concentrations in bone, liver and spleen may reflect Al sequestration. The skeletal system and lung have $\sim 50$ and 25\% of the 30-50 mg Al body burden of the normal human (ATSDR, 1999); brain has 1\%. Considering the Al species in plasma (Table 2), it is likely that $\mathrm{Al}$ transferrin and $\mathrm{Al}$ citrate account for the majority of the $\mathrm{Al}$ that distributes to tissues from the vascular compartment.

Iron status negatively correlates with tissue $\mathrm{Al}$ accumulation. This may be due to competition between these two chemically-similar trivalent cations, enabling greater transferrin-mediated extravascular distribution and ferritin storage of $\mathrm{Al}$ in the presence of low iron concentrations (Greger \& Sutherland, 1997).

$\mathrm{Al}$ citrate readily distributes out of blood. The effects of citrate on brain and bone Al concentrations and uptake of Al into cells have been inconsistent. Citrate forms a small molecular weight complex with $\mathrm{Al}$ that appears to enhance $\mathrm{Al}$ distribution and elimination when compared to $\mathrm{Al}$ transferrin (Maitani et al. 1994). In the presence of renal function, citrate may enhance $\mathrm{Al}$ clearance; in renal impairment citrate may enhance tissue $\mathrm{Al}$ accumulation.

Calculations show insignificant amounts of Al fluoride species will form in the presence of normal plasma fluoride $(\sim 100 \mu \mathrm{g} / \mathrm{l})$ and normal or elevated plasma $\mathrm{Al}$. This suggests fluoride is unlikely to affect $\mathrm{Al}$ distribution or elimination, unless fluoride and $\mathrm{Al}$ are involved in mixed ligand complexes involving other ligands (Wes Harris, personal communication). Similarly, silicon concentrations in biological fluids are very low. It was suggested that it is quite unlikely monomeric Al silicate species play any significant role in the biological chemistry of Al (Harris et al. in Yokel and Golub, 1996 \& 1997).

\section{A. Distribution into and out of the brain}

The brain has lower $\mathrm{Al}$ concentrations than many other tissues. Increased brain $\mathrm{Al}$ is seen in $\mathrm{Al}$-associated neurotoxicity in the human (Alfrey et al. 1980). Studies of AD victims inconsistently showed elevated brain $\mathrm{Al}$ (Yokel, 2000), contributing to the controversy concerning a possible role of $\mathrm{Al}$ in the etiology of this disease. Al can enter the brain from blood. This appears to occur by two processes. Roskams \& Connor (1990) provided evidence that transferrin can mediate Al transport across the blood-brain barrier by transferrin-receptor mediated endocytosis (TfR-ME) of Al transferrin, the 
predominant $\mathrm{Al}$ species in plasma (Table 2). Intravenous injection of ${ }^{26} \mathrm{Al}$ transferrin resulted in brain ${ }^{26} \mathrm{Al}$ concentrations $(\sim 0.003 \%$ of the injected dose/gm brain) within 4 hours (Yokel et al. 2000). TfR-ME could account for this appearance of $\mathrm{Al}$ in the brain if the rate of $\mathrm{Al}$ transport is similar to that reported for Fe. Transferrin increased in vitro Al uptake into neuroblastoma cells and oligodendroglia but not astrocytes (Golub et al. 1999), further suggesting transferrinmediated distribution of Al. Allen et al. (1995) gave Al citrate iv at a rate that produced plasma concentrations in excess of the ability of transferrin to bind the Al. This presumably permitted $\mathrm{Al}$ citrate to be the predominant $\mathrm{Al}$ species in plasma. The appearance of $\mathrm{Al}$ in brain extracellular fluid (ECF) was too rapid to be mediated by TfR-ME. This suggests a second mechanism transporting Al citrate across the blood-brain barrier into the brain that is independent of transferrin.

There appears to be a mechanism to transport $\mathrm{Al}$ out of the brain. When $\mathrm{Al}$ citrate was infused iv to produce constant brain and blood ECF $\mathrm{Al}$ concentrations, the brain ECF Al concentration was below that in blood ECF (Allen et al. 1995). This suggests a mechanism at the blood-brain barrier to reduce ECF brain Al by transporting it into blood. Transferrin concentration is very low in cerebrospinal fluid, and presumably brain ECF, whereas the citrate concentration is higher in brain ECF than in plasma, favoring $\mathrm{Al}$ citrate as the predominant $\mathrm{Al}$ species in brain ECF (Table 2). It is therefore likely that $\mathrm{Al}$ citrate is the $\mathrm{Al}$ species transported out of the brain. Genetic differences or competing ligands for these blood-brain barrier $\mathrm{Al}$ influx and efflux carriers may influence brain $\mathrm{Al}$ concentrations.

\section{B. Distribution into and out of bone}

Bone Al concentration in normal humans is a few-fold greater than brain Al, on a dry weight basis (Alfrey et al. 1980; Di Paolo et al. 1997). Al increased more in bone than brain in hemodialysis patients (Alfrey et al. 1980; Di Paolo et al. 1997). Humans with dialysis encephalopathy had brain and bone Al concentrations about 10- and 85-fold higher than controls, respectively (Alfrey et al. 1980). Several animal studies showed $\sim 100$-fold higher bone than brain ${ }^{26} \mathrm{Al}$ concentrations after a single ${ }^{26} \mathrm{Al}$ dose, suggesting greater $\mathrm{Al}$ entry into bone than brain. $\mathrm{Al}$ concentrates at the mineralization front of bone. 


\section{$V$. Elimination rates and tissue retention}

Plasma Al half-lives $(t / 2 \mathrm{~s})$ were summarized by Wilhelm et al. (1990). Elimination $t \frac{1}{2} \mathrm{~s}$ of years were seen after termination of occupational Al

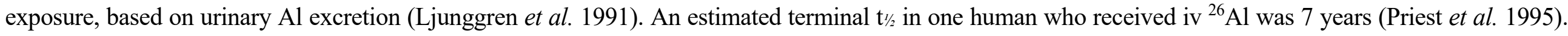
This kinetic behavior might result from retention of $\mathrm{Al}$ in a depot from which it is slowly eliminated. This depot is probably bone which stores $\sim 50 \%$ of the human Al body burden. Slow Al elimination coupled with continued exposure would be predicted to produce an increasing body burden with age. Brain, serum and bone Al have been reported to increase with age (Markesbery et al. 1984; Zapatero et al. 1995; Greger \& Sutherland, 1997).

There is more than one compartment of $\mathrm{Al}$ storage. The $t \frac{1 / 2}{2}{ }^{26} \mathrm{Al}$ in rat brain was $>100$ days following iv ${ }^{26} \mathrm{Al}$ transferrin dosing (Yokel et al. 2000 ). This is consistent with reports suggesting little decrease of brain Al in humans after renal transplantation and termination of the Al that had been given during renal failure. As noted above, injection of ${ }^{26} \mathrm{Al}$ increased bone ${ }^{26} \mathrm{Al} \sim 100$-fold more than brain, yet steady state bone $\mathrm{Al}$ concentration is $<100$-fold that of brain. This suggests Al clearance from bone is more rapid than from brain, which is reasonable considering bone turnover and lack of neuron turnover. The elimination $t \frac{1}{2}$ of $\mathrm{Al}$ from human brain is predicted to be very long. This is concluded from the $\mathrm{t} 1 / 2$ of $\mathrm{Al}$ in the tibia of rats, $38-173$ days $(\mathrm{Greger} \&$ Sutherland, 1997), compared to $>100$ days in brain, above, and a human ${ }^{26} \mathrm{Al} t \mathrm{t} / 2$ of 7 years, above, which is believed to be due to redistribution of Al out of bone.

\section{Excretion}

Urine accounts for $>95 \%$ of excreted Al. Reduced renal function increases the risk of Al accumulation and toxicity in the very young, elderly and renal diseased human (Greger \& Sutherland, 1997). Biliary Al accounts for $\leq 2 \%$ of total Al elimination in the human, dog, rabbit and rat (Priest et al. 1995; Kovalchik et al. 1978; Yokel et al. 1996; Yokel et al. unpublished results). Chelators can increase Al clearance into urine, bile and dialysate (Yokel et al. 1996; Yokel et al. in Yokel \& Golub, 1996 and 1997). Citrate appears to have chelation properties, to form small molecular weight Al species that can be excreted in the presence of adequate renal function, potentially protecting against the accumulation and toxicity of absorbed Al. 


\section{Summary}

Studies in the past decade, particularly those using physiologically-relevant doses of ${ }^{26} \mathrm{Al}$, have refined previous estimates of Al bioavailability from water and have provided Al biovailability estimates for inhalation, dermal and intramuscular exposure. The contribution of food to daily Al absorption, compared to other sources, needs to be determined to significantly advance the assessment of the major sources and routes of Al exposure in the human. 


\section{Acknowledgement}

This journal article is based on information contained in the report "Aluminum bioavailability (a compilation and critical review)" prepared under contract to Health Canada. This journal article does not necessarily reflect the policies or views of the Government of Canada. Any revisions to the information contained in the report "Aluminum bioavailability (a compilation and critical review)" resulting from the publication of this journal article are the sole responsibility of Dr. Robert Yokel and Health Canada will not be responsible for any such revision. Health Canada will not be liable for any reliance on the information in this journal article by any person. 


\section{References}

Alfrey, A. C., A. Hegg \& P. Craswell: Metabolism and toxicity of aluminum in renal failure. Am J. Clin. Nutr. 1980, 33, $1509-1516$.

Allain, P., F. Gauchard \& N. Krari: Enhancement of aluminum digestive absorption by fluoride in rats. Res. Commun. Mol. Pathol. Pharmacol. 1996, 91, $225-231$.

Allen, D. D., C. Orvig \& R. A. Yokel: Evidence for energy-dependent transport of aluminum out of brain extracellular fluid. Toxicol. 1995 , 98, $31-39$.

ATSDR (Agency for Toxic Substances and Disease Registry): Toxicological profile for aluminum (Update), U.S. Department of Health and Human Services, Public Health Service, 1999, 352 pp.

California EPA, Draft Public Health Goal for Aluminum in Drinking Water, Office of Environmental Health Hazard Assessment, 2000, 68pp, visit: http://www.oehha.ca.gov, Water, Public Health Goal, Aluminum.

Cannata Andía, J.B. Adynamic bone and chronic renal failure: An overview. Am. J. Med. Sci. 2000, 320, 81-84.

Di Paolo, N., A. Masti, I. B. Comparini, G. Garosi, M. Di Paolo, F. Centini, S. Brardi, G. Monaci \& V. Finato: Uremia, dialysis and aluminium. Int. J. Artif. Organs 1997, 20, 547-552.

Divine, K. K., J. L. Lewis, P. G. Grant \& G. Bench: Quantitative particle-induced X-ray emission imaging of rat olfactory epithelium applied to the permeability of rat epithelium to inhaled aluminum. Chem. Res. Toxicol. 1999, 12, 575-581.

Drueke, T. B., P. Jouhanneau, H. Banide, B. Lacour, F. Yiou \& G. Raisbeck: Effects of silicon, citrate and the fasting state on the intestinal absorption of aluminium in rats. Clin. Sci. (Colch.) 1997, 92, 63-67.

Edwardson, J. A., P. B. Moore, I. N. Ferrier, J. S. Lilley, G. W. Newton, J. Barker, J. Templar \& J. P. Day: Effect of silicon on gastrointestinal absorption of aluminium. Lancet 1993, 342, 211-212.

Flarend (Flack), R. \& D. Elmore: Aluminum-26 as a biological tracer using accelerator mass spectrometry. In: Aluminum Toxicity in Infant's Health and Disease. Eds.: P. Zatta \& A. C. Alfrey. World Scientific, Singapore, London, 1998, pp. 16-39. 
Flarend, R. E., S. L. Hem, J. L. White, D. Elmore, M. A. Suckow, A. C. Rudy \& E. A. Dandashli: In vivo absorption of aluminium-containing vaccine adjuvants using 26A1. Vaccine 1997, 15, 1314-1318.

Flarend, R., T. Bin, D. Elmore \& S. L. Hem: A preliminary study of dermal absorption of aluminum from antiperspirants using aluminum-26. Fd. Chem. Toxicol. 2001, accepted for publication.

Gitelman, H. J., F. R. Alderman, M. Kurs-Lasky \& H. E. Rockette: Serum and urinary aluminium levels of workers in the aluminium industry. Ann. Occup. Hyg. 1995, 39, 181-191.

Golub, M. S., B. Han \& C. L. Keen: Aluminum uptake and effects on transferrin mediated iron uptake in primary cultures of rat neurons, astrocytes and oligodendrocytes. NeuroToxicology 1999, 20, 961-970.

Greger, J. L. \& J. E. Sutherland: Aluminum exposure and metabolism. Crit. Rev. Clin. Lab. Sci. 1997, 34, 439-474.

Health Canada, Aluminum, Environmental Health Program: 22 pp., 1998, Visit: http://www.hc-sc.gc.ca, A-Z index, Aluminum, Search for More.

Hohl, C., P. Gerisch, G. Korschinek, E. Nolte \& T. H. Ittel: Medical application of 26-Al. Nucl. Instr. Meth. Physics Res. 1994, B 92, 478-482.

Jouhanneau, P., B. Lacour, G. Raisbeck, F. Yiou, H. Banide, E. Brown \& T. Drueke: Gastrointestinal absorption of aluminum in rats using 26Al and accelerator mass spectrometry. Clin. Nephrol. 1993, 40, 244-248.

Jouhanneau, P., G. M. Raisbeck, F. Yiou, B. Lacour, H. Banide \& T. B. Drueke: Gastrointestinal absorption, tissue retention, and urinary excretion of dietary aluminum in rats determined by using 26Al. Clin. Chem. 1997, 43, 1023-1028.

Jugdaohsingh, R., D.M. Reffitt, C. Oldham, J.P. Day, L.K. Fifield, R.P.H. Thompson \& J.J. Powell: Oligomeric but not monomeric silica prevents aluminum absorption in humans. Am. J. Clin. Nutr. 2000,71, 944-949.

Kovalchik, M. T., W. D. Kaehny, A. P. Hegg, J. T. Jackson \& A. C. Alfrey: Aluminum kinetics during hemodialysis. J. Lab. Clin. Med. 1978, 92, 712720.

Ljunggren, K. G., V. Lidums \& B. Sjogren: Blood and urine concentrations of aluminium among workers exposed to aluminium flake powders. Br. $J$. Ind. Med. 1991, 48, 106-109. 
Maitani T, H. Kubota, N. Hori, K. Yoshihira \& M. Takeda. Distribution and urinary excretion of aluminium injected with several organic acids into mice: relationship with chemical state in serum studied by the HPLC-ICP method. J. Appl. Toxicol.1994,14,257-261

Markesbery, W. R., W. D. Ehmann, M. Alauddin \& T. I. Hossain: Brain trace element concentrations in aging. Neurobiol. Aging 1984, 5, 19-28.

Nieboer, E., B.L. Gibson, A.D. Oxman \& J.R. Kramer: Health effects of aluminum: a critical review with emphasis on aluminum in drinking water. Environ. Rev. 1995, 3, 29-81.

Pennington, J. A.: Aluminium content of foods and diets. Fd. Addit. Contam. 1987, 5, 161-232.

Pennington, J. A. T. \& S. A. Schoen: Estimates of dietary exposure to aluminium. Fd. Addit. Contam. 1995, 12, 119-128.

Perl, D. P. \& P. F. Good: Uptake of aluminium into central nervous system along nasal-olfactory pathways. Lancet $1987, \mathbf{1}, 1028$.

Pierre, F., F. Baruthio, F. Diebold \& P. Biette: Effect of different exposure compounds on urinary kinetics of aluminium and fluoride in industrially exposed workers. Occup. Environ. Med. 1995, 52, 396-403.

Powell, J. J., M.W. Whitehead, C.C. Ainley, M.D. Kendall, J.K. Nicholson \& R. P. H. Thompson: Dietary minerals in the gastrointestinal tract: hydroxypolymerisation of aluminium is regulated by luminal mucins. J. Inorg. Biochem. 1999,75, 167-180.

Priest, N. D., D. Newton, J. P. Day, R. J. Talbot \& A. J. Warner: Human metabolism of aluminium-26 and gallium-67 injected as citrates. Hum. Exp. Toxicol. 1995, 14, 287-293.

Priest, N. D., R. J. Talbot, J. G. Austin, J. P. Day, S. J. King, K. Fifield \& R. G. Cresswell: The bioavailability of ${ }^{26}$ Al-labelled aluminium citrate and aluminium hydroxide in volunteers. Biometals 1996, 9, 221-228.

Priest, N. D., R. J. Talbot, D. Newton, J. P. Day, S. J. King \& L. K. Fifield: Uptake by man of aluminium in a public water supply. Hum. Exp. Toxicol. $1998,17,296-301$.

Reiber, S., W. Kukull \& P. Standish-Lee: Drinking water aluminum and bioavailability. Journal AWWA 1995, 87, 86-100.

Riihimäki, V., Hänninen, H., Akila, R., Kovala, T., Kuosma, E., Paakkulainen, H., Valkonen, S. \& Engström, B. Body burden of aluminum in relation to central nervous system function among metal inert-gas welders. Scand. J. Work Environ. Health 2000, 26, $118-130$. 
Sjögren, B., V. Lidums, M. Håkansson \& L. Hedström: Exposure and urinary excretion of aluminum during welding. Scand. J. Work Environ. Health 1985, 11, 39-43.

Stauber, J. L., T. M. Florence, C. M. Davies, M. S. Adams \& S. J. Buchanan: Bioavailability of Al in alum-treated drinking water. Journal AWWA 1999, 91, 84-93.

Taylor, G. A., P. B. Moore, I. N. Ferrier, S. P. Tyrer \& J. A. Edwardson: Gastrointestinal absorption of aluminium and citrate in man. J. Inorg. Biochem. 1998, 69, 165-169.

Tjalve, H. \& J. Henriksson: Uptake of metals in the brain via olfactory pathways. NeuroToxicology 1999, 20, 181-195.

US EPA, Announcement of the Drinking Water Contaminant Candidate List, Fed Register 1998; 63:10273-10287; http://wais.access.gpo.gov.

US FDA, Aluminum in large and small volume parenterals used in total parenteral nutrition, Code of Federal Regulations 21CFR201.323; http://wais.access.gpo.gov.

van der Voet, G. B. \& F.A. de Wolff: Intestinal absorption of aluminium: effect of sodium and calcium. Arc.h Toxicol. 1998,72,110-114.

Walton, J., G. Hams \& D. Wilcox: Bioavailability of aluminium from drinking water: Co-exposure with foods and beverages. Urban Water Research Association of Australia, Melbourne, 1994.

Wilhelm, M., D. E. Jäger \& F. K. Ohnesorge: Aluminium toxicokinetics. Pharmacology \& Toxicology 1990, 66, 4-9.

Yokel, R. A.: The toxicology of aluminum in the brain: A review. NeuroToxicology, 21, 813-828, 2000.

Yokel, R.A. \& M.S. Golub, Eds.: J. Toxicol. Environ. Health 1996, 48, 527-686. This issue contains 9 papers from a July 8, 1995 workshop "Research Issues in Aluminum Toxicity".

Yokel, R.A. \& M.S. Golub, Eds.: Research Issues in Aluminum Toxicity, 1997 (this book contains the 9 papers published in Yokel \& Golub, 1996 plus 4 additional chapters), Taylor and Francis, Washington, D.C.

Yokel, R. A., K. A. Meurer, T. L. Skinner \& A. M. Fredenburg: The 3-hydroxypyridin-4-ones more effectively chelate aluminum in a rabbit model of aluminum intoxication than does desferrioxamine. Drug Metab. Disp. 1996, 24, 105-111. 
Yokel, R.A., S.S. Rhineheimer, P. Sharma, D. Elmore \& P.J. McNamara: Brain aluminum clearance is slow. Tox. Sci. $2000,54,35$.

Yokel, R.A., S.S. Rhineheimer, R.D. Brauer, P. Sharma, D. Elmore, \& P.J. McNamara: Aluminum bioavailability from drinking water is very low and is not influenced by stomach contents or water hardness. Toxicology, accepted for publication, 2001.

Zapatero, M. D., A. Garcia de Jalon, F. Pascual, M. L. Calvo, J. Escanero \& A. Marro: Serum aluminum levels in Alzheimer's disease and other senile dementias. Biol. Trace Elem. Res. 1995, 47, 235-240. 
Table 1. Common sources of Al for the human, Al concentration in the source, resultant daily Al exposure from the source, estimated bioavailability from the source and calculated amount of $\mathrm{Al}$ absorbed daily.

\begin{tabular}{|c|c|c|c|c|}
\hline SOURCE & $\begin{array}{c}\mathrm{Al} \\
\text { CONCENTRATION }\end{array}$ & $\begin{array}{c}\text { DAILY Al } \\
\text { EXPOSURE }\end{array}$ & $\begin{array}{c}\text { ESTIMATED } \\
\text { PERCENTAGE } \\
\text { ABSORBED }\end{array}$ & $\begin{array}{c}\text { DAILY Al } \\
\text { ABSORBED } \\
(\mu \mathrm{g} / \mathrm{kg})^{\mathrm{a}} \\
\end{array}$ \\
\hline \multicolumn{5}{|l|}{ Normal Exposure } \\
\hline Water & Average $\sim 70 \mu \mathrm{g} / 1$ & $100 \mu \mathrm{g}$ & $0.3^{\mathrm{b}}$ & 0.005 \\
\hline Food & & $5000-10,000 \mu \mathrm{g}^{\mathrm{c}}$ & $0.1-0.3^{d}$ & $0.08-0.5$ \\
\hline Air-rural & $0.2 \mu \mathrm{g} / \mathrm{m}^{3}$ & $4 \mu \mathrm{g}$ & $\begin{array}{l}\text { 1.5-2 from lungs }{ }^{\mathrm{e}} \\
0.1-0.3 \text { from GI tract }\end{array}$ & $\begin{array}{l}0.001 \\
0.0001\end{array}$ \\
\hline Air-urban & $1 \mu \mathrm{g} / \mathrm{m}^{3}$ & $20 \mu \mathrm{g}$ & $\begin{array}{l}\text { 1.5-2 from lungs }{ }^{\mathrm{e}} \\
0.1-0.3 \text { from GI tract }\end{array}$ & $\begin{array}{l}0.006 \\
0.0006\end{array}$ \\
\hline Antiperspirants & $5-7.5 \%{ }^{f}$ & $50,000-75,000 \mu \mathrm{g}$ & up to $0.012^{\mathrm{g}}$ & up to 0.1 \\
\hline Vaccines & $150-850 \mu \mathrm{g} /$ dose & $1.4-8 \mu \mathrm{g}^{\mathrm{h}}$ & 100 eventually $^{i}$ & $0.07-0.4$ \\
\hline \multicolumn{5}{|l|}{ Elevated Exposure } \\
\hline $\begin{array}{l}\text { Antacids/phosphate } \\
\text { Binders }\end{array}$ & & up to $5,000,000 \mu \mathrm{g}$ & 0.1 & 80 \\
\hline Industrial Air & $25-2500 \mu \mathrm{g} / \mathrm{m}^{3}$ & $\begin{array}{l}250-25,000 \mu \mathrm{g} \text { per } \\
\text { work day }\end{array}$ & $\begin{array}{l}1.5-2 \text { from lungs }{ }^{\mathrm{e}} \\
0.1-0.3 \text { from GI tract }\end{array}$ & $\begin{array}{l}0.6-8 \\
0.008-1\end{array}$ \\
\hline Allergy immunotherapy & $150-850 \mu \mathrm{g} /$ dose & $7-40 \mu \mathrm{g}^{\mathrm{j}}$ & 100 eventually $^{\mathrm{i}}$ & $0.1-0.6$ \\
\hline Dialysis solution & If tap water $50 \mu \mathrm{g} / 1$ & $2400 \mu \mathrm{g}$ & $25^{\mathrm{k}}$ & 9 \\
\hline \multirow[t]{2}{*}{$\begin{array}{l}\text { Total Parenteral } \\
\text { Nutrition Solutions }\end{array}$} & $\begin{array}{l}\text { Neonatal/pediatric } \\
110-270 \mu \mathrm{g} / 1^{1}\end{array}$ & $11-27 \mu \mathrm{g} / \mathrm{kg}$ & 100 & $11-27$ \\
\hline & Adult $40-135 \mu \mathrm{g} / 1^{1}$ & $80-270 \mu \mathrm{g}$ & 100 & $1.2-4.2$ \\
\hline
\end{tabular}

${ }^{a}$ Based on a $65 \mathrm{~kg}$ adult except for vaccines (20 kg child) and total parenteral nutrition solution in neonates and pediatrics.

${ }^{\mathrm{b}}$ From Table 3.

c Pennington \& Schoen (1995).

${ }^{\mathrm{d}}$ Estimates based on daily urinary Al excretion/daily Al intake from food and Stauber et al. (1999).

${ }^{\mathrm{e}}$ Based on Al exposure in an industrial setting: Gitelman et al. (1995); Pierre et al. (1995).

${ }^{\mathrm{f}}$ Based on $20 \% \mathrm{Al}$ zirconium glycine complex or $25 \% \mathrm{Al}$ chlorohydrate in a topical product, which are typical concentrations (POISINDEX information system, Micromedex, Inc, Englewood, CO).

$\mathrm{g}$ Based on Flarend et al. (2001), assuming that the percentage of Al absorbed does not change with repeated exposure.

${ }^{\mathrm{h}}$ Based on 20 injections in the first 6 years of life and an average weight of $20 \mathrm{~kg}$.

${ }^{\text {i }}$ Flarend et al. (1997).

${ }^{\mathrm{j}}$ Based on a typical allergen extract treatment schedule and maintenance injections for 3.5 years of one allergen extract.

${ }^{\mathrm{k}}$ Kovalchik et al. (1978).

${ }^{1}$ Based on maintenance fluids and normal neonatal/pediatric or adult electrolyte supplementation. 
Table 2. The predominant binding ligands for $\mathrm{Al}$ in vivo, their effective equilibrium constants with $\mathrm{Al}$, their concentrations in plasma and brain extracellular fluid (based on values in cerebrospinal fluid), and the percentage of Al predicted to be associated with that ligand. (Provided by Wes Harris).

\begin{tabular}{|c|c|c|c|c|c|}
\hline \multirow[t]{2}{*}{ LIGAND } & \multirow{2}{*}{$\begin{array}{c}\text { EFFECTIVE } \\
\text { EQUILIBRIUM } \\
\text { CONSTANT } \\
\text { WITH Al } \\
(\log )\end{array}$} & \multicolumn{2}{|c|}{ PLASMA } & \multicolumn{2}{|c|}{ BRAIN EXTRACELLULAR FLUID } \\
\hline & & $\begin{array}{c}\text { CONCENTRATION } \\
(\mu \mathrm{mol} / 1)\end{array}$ & $\begin{array}{l}\% \text { OF Al } \\
\text { SPECIES }\end{array}$ & $\begin{array}{c}\text { CONCENTRATION } \\
(\mu \mathrm{mol} / 1)\end{array}$ & $\%$ OF Al SPECIES \\
\hline Transferrin & $13.7,12.6$ & 30 & 91 & $<0.25$ & 4 \\
\hline Citrate & 11.6 & 99 & $7-8$ & 180 & 90 \\
\hline Hydroxide (free) & 6.5 & 0.4 & $<1$ & 0.4 & 5 \\
\hline Phosphate & 9.3 & 1100 & $<1$ & 490 & 1 \\
\hline
\end{tabular}


Table 3. Oral Al bioavailability determined in studies that model drinking water consumption.

\begin{tabular}{|c|c|c|c|}
\hline SUBJECT & Al ADMINISTERED & $\begin{array}{l}\text { ORAL Al } \\
\text { BIOAVAILABILITY } \\
\text { EXPRESSED AS \% by } \\
\left.[\text { METHOD }]^{\mathrm{a}}\right]\end{array}$ & REFERENCE \\
\hline Rat & $\begin{array}{l}3.8 \mathrm{ng}{ }^{26} \mathrm{Al}+63 \mathrm{ng}{ }^{27} \mathrm{Al}(\text { total } \mathrm{Al} \sim 0.27 \mu \mathrm{g} / \mathrm{kg}) \\
\text { in distilled water }\end{array}$ & $\begin{array}{l}0.04 \\
{[2+\text { bone }]}\end{array}$ & $\begin{array}{l}\text { Jouhanneau et al. } \\
\text { (1993). }\end{array}$ \\
\hline Rat & $\begin{array}{l}3.8 \mathrm{ng}{ }^{26} \mathrm{Al}+63 \mathrm{ng}{ }^{27} \mathrm{Al}(\text { total } \mathrm{Al} \sim 0.22 \mu \mathrm{g} / \mathrm{kg}) \\
\text { in } \mathrm{HCl} @ \mathrm{pH} 1.9\end{array}$ & $\begin{array}{l}\sim 0.1 \\
{[2+\text { bone, liver \& brain }]}\end{array}$ & $\begin{array}{l}\text { Jouhanneau et al. } \\
\text { (1997). }\end{array}$ \\
\hline Rat & $\begin{array}{l}3.8 \mathrm{ng}{ }^{26} \mathrm{Al}+63 \mathrm{ng}{ }^{27} \mathrm{Al} \text { (total } \mathrm{Al} \sim 0.24 \mu \mathrm{g} / \mathrm{kg} \text { ) } \\
\text { @ } \mathrm{pH} 1.6-2\end{array}$ & $\begin{array}{l}0.06 \\
{[2+\text { bone } @ 48 \text { hrs }]}\end{array}$ & $\begin{array}{l}\text { Drueke et al. } \\
\text { (1997). }\end{array}$ \\
\hline Rat & $\begin{array}{l}74.5 \mathrm{ng}{ }^{26} \mathrm{Al}+552 \mathrm{ng}{ }^{27} \mathrm{Al} \text { (total } \mathrm{Al} \sim 2.3 \mu \mathrm{g} / \mathrm{kg} \text { ) @ } \mathrm{pH} 5 \\
1 \& \text { 2) in dilute } \mathrm{HCl} \\
3 \& 4 \text { ) plus } 90: 1 \mathrm{Ca}: \mathrm{Al} \text { and } 13: 1 \mathrm{Mg}: \mathrm{Al} \text {, as } \mathrm{CaCO}_{3} \& \mathrm{Mg} \mathrm{CO}_{3} \\
1 \& 3 \text { ) no food in stomach } \\
2 \& 4 \text { ) food in stomach }\end{array}$ & $\begin{array}{ll}\text { 1) } & 0.23 \\
\text { 2) } & 0.21 \\
\text { 3) } & 0.24 \\
\text { 4) } & 0.41 \\
{[3]} & \end{array}$ & Yokel et al. (2001). \\
\hline Human & $\begin{array}{l}100 \mathrm{ng}{ }^{26} \mathrm{Al}+100 \mu \mathrm{g}{ }^{27} \mathrm{Al}(\text { total } \mathrm{Al} \sim 1.4 \mu \mathrm{g} / \mathrm{kg}) \\
\text { as } \mathrm{AlCl}_{3}\end{array}$ & $\begin{array}{l}0.1 \& 0.24 \text { in } 2 \text { subjects } \\
{[2]}\end{array}$ & Hohl et al. (1994). \\
\hline Human & $\begin{array}{l}141 \mathrm{ng}{ }^{26} \mathrm{Al}+12.5 \mu \mathrm{g}{ }^{27} \mathrm{Al} \text { (total } \mathrm{Al} \sim 0.2 \mu \mathrm{g} / \mathrm{kg} \text { ) } \\
\text { in public water from near Sydney, @ } \mathrm{pH} 6.5\end{array}$ & $\begin{array}{l}0.22 \\
{[2]}\end{array}$ & Priest et al. (1998). \\
\hline Human & $\begin{array}{l}224 \mu \mathrm{g}{ }^{27} \mathrm{Al} / \text { day for } 2 \text { days in } \mathrm{pH} 7 \text { alum-treated water from a } \\
\text { municipal water treatment plant versus reconstituted soft water } \\
\text { containing }<1 \mu \mathrm{g}{ }^{27} \mathrm{Al} / 1\end{array}$ & $\begin{array}{l}0.36 \\
{[2]}\end{array}$ & $\begin{array}{l}\text { Stauber et al. } \\
\text { (1999). }\end{array}$ \\
\hline
\end{tabular}


${ }^{a}$ METHODS For details, see 1. Methods to determine oral Al bioavailability.

$2=$ Bioavailability based on urinary Al excretion/dose.

3 = Bioavailability based on comparison of area under the serum Al concentration $\times$ time curve after oral and intravenous dosing. 